Osoba i doświadczenie mistyczne (3) „Filozofia Chrześcijańska” 15 (2018), s. 59-81 doi: $10.14746 /$ fc. 2018.15 .3

JAN GRZESZCZAK

Uniwersytet im. Adama Mickiewicza w Poznaniu

Wydział Teologiczny

\title{
Czy Joachim z Fiore byl mistykiem? Kilka uwag na temat apokaliptycznej duchowości kalabryjskiego opata
}

Początek tych rozważań na temat Joachimowej mistyki zabrzmi nieco pesymistycznie. W drugim tomie Duchowości chrześcijańskiej, obejmującym późne średniowiecze i reformację, George Tovard poświęca dwie strony Joachimowi z Fiore. Konkluzja jego rozważań nie zachęca jednak zbytnio do dalszych badań nad mistyką tego XII-wiecznego autora:

To, czy Joachim sam był mistykiem i czy jego udziałem były szczególne łaski w sferze duchowego poznania, wydaje się wątpliwe. Miał natomiast niezaprzeczalne zdolności pedagogiczne. Liczne ilustracje obecne w jego dziełach przywodzą na myśl dążenia Hildegardy do holistycznego ujęcia życia duchowego. Obrazki Joachima inspirowane są gotyckim rysunkiem architektonicznym oraz iluminacjami manuskryptów. Należą do gatunku, który można nazwać świętą geometrią: są na nich splatające się okręgi, orły w kształcie drzew, trójkąty, koła, kwadraty i linie proste, wszystkie opatrzone nazwami i słowami zaczerpniętymi z Pisma Świętego. Joachim upodobał sobie rysowanie liści, ale także dzikich zwierząt - zarówno istniejących, jak i mitycznych: smoków, węży i siedmiogłowych bestii. Jego rysunki nie stanowią pokarmu dla duszy. Są raczej mnemotechnicznym wsparciem dla umysłu niż mandalą otwierającą oczy na niedostrzegane dotychczas perspektywy ${ }^{1}$.

${ }^{1}$ G.H. Tovard, Życie apostolskie i reforma Kościoła, w: Duchowość chrześcijańska. Późne średniowiecze i reformacja, red. J. Raitt, współpr. B. McGinn, J. Meyendorff, tłum. P. Blumczyński, Kraków 2011, s. 6. 
Joachim z Fiore (ok. 1135-1202), o którym Dante Alighieri napisał, że był kalabryjskim opatem obdarzonym duchem proroctwa ${ }^{2}$, jest po dziś dzień uznawany za ojca wielu pełnych rozmachu wizji odnowy świata, które spoczywają na olbrzymim cmentarzu z ciekawymi nagrobkami, do którego Mieczysław Albert Krąpiec porównał kiedyś pole historii filozofii ${ }^{3}$. Tak się składa, że wiele filozoficznych stanowisk zainspirowanych myślą Joachima z Fiore należy do tej kategorii pochówków, które - jak pisze lubelski profesor - „[...] jeszcze zatruwają powietrze szkodliwymi społecznie poglądami"4.

Zadziwiająca rozmachem Joachimowa wizja tertius status, czyli epoki Ducha Świętego, poprzedzającej koniec świata, u schyłku średniowiecza i na progu czasów nowożytnych zainspirowała w większym lub mniejszym stopniu rozmaite ruchy i wspólnoty w obrębie Kościoła lub te, które znalazły się poza katolicką ortodoksją. W pewnym jednak momencie także wzrok XVIII-wiecznych niemieckich intelektualistów spoczął na średniowiecznych pergaminach zgromadzonych w tamtejszych bibliotekach i archiwach od czasu, kiedy reformacja, likwidując klasztory, wyrzuciła z nich mnichów i przejęła ich czcigodne biblioteki. Lektura tych reliktów średniowiecza, prowadzona przez ówczesnych niemieckich erudytów w zaciszu bibliotecznych czytelni, po raz kolejny roznieciła ogień „wieczystej Ewangelii”, jaki płonął w sercach średniowiecznych radykałów. Tym razem jednak fascynacji Joachimem ulegli ludzie Oświecenia.

Wydaje się, że uległ jej też Gotthold Ephraim Lessing (1729-1781). Dnia 4 maja 1770 roku przybył do położonego w Dolnej Saksonii Wolfenbüttel z zadaniem uporządkowania tamtejszej książęcej biblioteki. Adolf Sowiński, autor $W$ stępu do trzytomowego wydania jego Dziet wybranych tak wyobraża sobie to, co niemiecki myśliciel tam zastał:

Gdy dwór książęcy zdecydował się przenieść do pobliskiego Brunszwiku, nie znaleziono w tamtejszym pałacu pomieszczenia dla olbrzymiej biblioteki nagromadzonej w ciągu całych stuleci. Pozostawiono ją w opustoszałym i wyziębionym zamku, który przestał być rezydencją. Foliały i manuskrypty zarosły kurzem, stęchlizna zagęściła się $\mathrm{w}$ nie przewietrzanych komnatach, po których nocami grasowały myszy, a w dzień pracowały niezmordowanie skrzętne pająki, zasnuwając coraz to nowymi sieciami grzbiety dzieł oprawnych w drewno i skórę. Biblioteka, tak niegdyś, w latach 1690-1716, kwitnąca pod mądrym i czujnym okiem Leibniza, obumierała 5 .

2 „Il calavrese abate Giovacchino, /Di spirito profetico dotato" - Dante Alighieri, La Divina Commedia, Paradiso, Canto XII, 140-141, Milano 1962, s. 448.

${ }^{3}$ Zob. M.A. Krąpiec, Okresy i główne nurty filozofii, w: Wprowadzenie do filozofii, red. M.A. Krąpiec $i$ in., Lublin $1996^{2}$, s. 33.

4 Tamże.

5 A. Sowiński, Wstęp, w: G.E. Lessing, Dzieła wybrane, t. 1, Warszawa 1959, s. LII. 
W napisanym przez Lessinga na rok przed śmiercią Wychowaniu rodzaju ludzkiego pobrzmiewają echa kontaktu z tym dziedzictwem dawnych epok:

Musi przyjść lepszy pedagog, który wyrwie z rąk dziecka przestarzały elementarz. - Przyszedł Chrystus [...]

Nadejdzie z pewnością czas nowej, wiecznej Ewangelii, którą nam obiecano w elementarzach Nowego Zakonu.

Niektórzy marzyciele XIII i XIV wieku pochwycili, być może, jakiś promień tej nowej, wiecznej Ewangelii; pomylili się tylko, głosząc zbyt rychłe jej nastanie.

Być może, ich „trzy epoki świata” nie były jedynie czczą chimerą, nie mieli na pewno złych zamiarów nauczając, że Nowy Zakon stanie się tak samo przestarzały, jak Stary. I oni trzymali się ustawicznie tych samych praw tego samego Boga. Czyli - każąc im mówić moim językiem - tego samego ogólnego planu wychowania rodzaju ludzkiego ${ }^{6}$.

Charakterystyczne dla czasów nowożytnych przetransponowanie myślenia eschatologicznego na „rzeczy przedostatnie”, o którym pisał Karl Löwith w swojej pracy Historia powszechna $i$ dzieje zbawienia, spowodowało, że Joachimowa wizja nie pozostała tylko w pokrytych kurzem i pajęczynami średniowiecznych rękopisach, lecz zainspirowała, przynajmniej po części, widoczne w XX wieku zjawisko ubóstwienia świata i człowieka, którego punktem kulminacyjnym były triumfujące wówczas ustroje totalitarne ${ }^{7}$. Przywołany wyżej Karl Löwith tak opisuje ten złożony proces współczesnej recepcji myśli kalabryjskiego opata: „Trzeci Testament joachitów pojawił się znowu jako «Trzecia Międzynarodówka» oraz jako «Trzecia Rzesza», zwiastowany przez jakiegoś dux czy führera, który jako Zbawca był entuzjastycz-

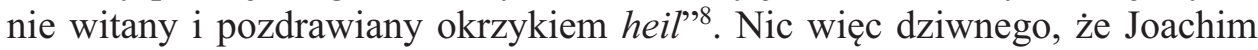
z Fiore pojawia się zarówno w rozprawach poświęconych marksizmowi i komunizmowi, jak i u klasyków historii myśli średniowiecznej ${ }^{9}$.

${ }^{6}$ G.E. Lessing, Wychowanie rodzaju ludzkiego, 53, 86-88, tłum. H. Kahanowa, w: tenże, Dzieła wybrane, t. 3, s. 545, 552-553; zob. H. de Lubac, La posterité spirituelle de Joachim de Flore. De Joachim à nos jours, Paris 2014, s. 266-279; W. Gould, M. Reeves, Joachim of Fiore and the Myth of the Eternal Evangel in the Nineteenth and Twentieth Century. Revised and enlarged Edition, Oxford 2001, s. 76-77.

7 Zob. K. Löwith, Historia powszechna $i$ dzieje zbawienia. Teologiczne przesłanki filozofii dziejów, thum. J. Marzęcki, Kęty 2002, s. 153; M. Scattola, Teologia polityczna, tłum. P. Borkowski, Warszawa 2011, s. 198.

${ }^{8}$ K. Löwith, Historia powszechna i dzieje zbawienia, s. 153.

9 Zob. L. Kołakowski, Glówne nurty marksizmu, t. 1: Powstanie, Poznań 2001, s. 105; G. Weigel, Ostateczna rewolucja. Kościót sprzeciwu a upadek komunizmu, thum. W. Buchner, Poznań 1995, s. 35-42. Należy jednak zauważyć brak jakiegokolwiek odwołania do myśli Joachima z Fiore w klasycznym studium É. Gilsona, poświęconym historii filozofii w średniowieczu - zob. A. Tagliapietra, Gioacchino 
Daleko idącą reinterpretację Joachimowego przesłania o epoce Ducha Świętego znaleźć można w rozważaniach na temat zasady nowożytności, widocznych w Zachodniej eschatologii Jacoba Taubesa ${ }^{10}$. W tej opublikowanej w 1947 roku i pełnej rozmachu rozprawie Taubes posługuje się ptolemejską i kopernikańską terminologią, którą wyrywa jednak z jej pierwotnego, astronomicznego środowiska i umieszcza w kontekście teologicznym. Podczas gdy światopogląd ptolemejski, właściwy średniowieczu, zakłada, że ziemia ma nad sobą niebo

Wedle kopernikańskiego światopoglądu - pisze Taubes - świat jest ziemią pozbawioną nieba. Ziemia nie odzwierciedla już żadnego nieba, a kopernikańska ludzkość nie osiąga autentyczności świata przez to, że zbliża się do jakiegoś praobrazu, lecz przez to, że rewolucjonizuje świat ku ideałowi leżącemu w przyszłości. W ptolemejskim światopoglądzie panuje platoński Eros, który zbliża do siebie górę i dól, podczas gdy w świecie kopernikańskim panuje duch, który zmierza naprzód. Etosem człowieka kopernikańskiego jest etos przyszłości ${ }^{11}$.

Nawiązując do ogólnych założeń, przyjętych już w dziele Lessinga, Taubes uważa, że początki tak rozumianego kopernikanizmu widoczne są już u Joachima z Fiore, który usunął ,granicę dzielącą to, co ziemskie, od tego, co niebiańskie, umieszczając spełnienie w ściśle datowalnej, nieodległej przyszłości ${ }^{12}$.

O sile oddziaływania wizji kalabryjskiego opata świadczy również widoczna u Gianniego Vattimo próba jej zestawienia z głównymi tezami, składającymi się na charakterystyczną dla tego włoskiego filozofa odmianę postmodernizmu, znaną jako pensiero debole:

Osiągnięty obecnie poziom cywilizacyjny, charakteryzujący się automatyzacją i informatyką, wraz z demokracją i społecznym pluralizmem, powszechną dostępnością dóbr koniecznych do zagwarantowania przeżycia, daje chance na realizację królestwa ducha rozumianego jako uwolnienie od ciężaru rzeczywistości i jej swoistą ,poetyzację”. Twierdzę, że stwarza chance, ponieważ wiem dobrze, że „poetyzacja” ta pozostaje obecnie całkowicie w sferze wyobraźni. Także Joachim, kiedy mówił o początku epoki Ducha, przewidywał konieczność ciężkiej walki, poprzedzającej jej rzeczywiste nastanie w jego świecie. Tak samo spirytualizacja, która jest dzisiaj w zasięgu ręki, przynajmniej na płaszczyźnie możliwości technicznych i ewolucji idei, wymaga działania, które w żadnym wypadku nie przed-

da Fiore e la filosofia, Saonara 2013, s. 78; É. Gilson, Historia filozofii chrześcijańskiej w wiekach średnich, thum. S. Zalewski, Warszawa 1987.

10 Zob. J. Taubes, Zachodnia eschatologia, thum. A. Serafin, Warszawa 2016.

11 Tamże, s. 107.

12 Tamże. 
stawia się jako coś łatwego. Pozory łatwości i braku moralnego zaangażowania, jakie mogłaby wzbudzić, są związane z faktem, że ideał zbawienia lub wyzwolenia, które zapowiada, ma silne konotacje estetyczne i poetyckie. Są to jednak jedyne konotacje, które potrafią wypełnić treścią zapowiedź, w przeciwnym razie pustą, „Zamknięcia” ludzkiej historii, jakkolwiek to zamknięcie chcielibyśmy sobie wyobrazić: pojmowane jako télos wyzwolenia, które nadałoby sens życiu każdego z nas, zawartemu w nieprzekraczalnych granicach wyznaczonych przez ziemskie narodziny i śmierć, bądź też jako stan, który nastąpi w życiu wiecznym po śmierci. Także w tym drugim przypadku - a tak nauczał Joachim i tak też podchodzi do tego (moja) filozofia - zbawienie musi się rozpocząć na tym świecie, $\mathrm{w}$ przeciwnym razie cały proces jego przygotowania byłby pozbawiony sensu, a inicjatywa $\mathrm{w}$ grze zostałaby powierzona bóstwu transcendentnemu, niezależnie od naszej zdolności do uczestnictwa w niej. [O tej ewentualności] byłoby więc lepiej w ogóle nie wspominać ${ }^{13}$.

To dość obszerne wprowadzenie ma na celu zapoznanie czytelnika z fenomenem Joachimowej spuścizny, której cechą charakterystyczną jest niespotykany gdzie indziej rozmach dziejowej wizji. Jej sugestywność i widoczna w kolejnych wiekach obecność nie tylko zadziwia, ale budzi też pytania o jej istotę, które warto sobie postawić, podejmując refleksję nad doświadczeniem mistycznym we wczesnym średniowieczu.

\section{Apokaliptyczna duchowość w Joachimowym wydaniu}

Zamknijmy jednak za sobą cmentarną furtkę i przejdźmy do właściwego tematu, próbując odpowiedzieć na pytanie, czy Joachim z Fiore był mistykiem. Pogłębione badania nad Joachimem z Fiore, prowadzone już od pierwszej połowy $\mathrm{XX}$ wieku, zaowocowały ciekawymi syntezami myśli tego średniowiecznego autora, wydobywającymi na światło dzienne jej oryginalne elementy ${ }^{14}$. Nie ulega wątpliwości, że Joachim z Fiore jest przedstawicielem tej średniowiecznej duchowości, którą należałoby opatrzyć jeszcze jednym przymiotnikiem. W jego przypadku mówimy o „duchowości apokaliptycznej”. Tak ją określa Bernard McGinn, który w swoich klasycznych już opracowaniach wskazuje na kilka stałych elementów, pozwalających na mówienie o apokaliptycznej duchowości, będącej reakcją na głębokie kryzysy, o których

13 G. Vattimo, Dopo la cristianità. Per un cristianesimo non religioso, Milano 2002, s. 57-58. Tłum. autora.

${ }^{14}$ Zob. H. Grundmann, Studien über Joachim von Floris, Leipzig-Berlin 1927; M. Reeves, The Influence of Prophecy in the Later Middle Ages. A Study in Joachimism, Oxford 1969, London 19932; B. McGinn, The Calabrian Abbot. Joachim of Fiore in the History of Western Thought, New York 1985; G.L. Potestà, Il tempo dell'Apocalisse. Vita di Gioacchino da Fiore, Roma-Bari 2004. 
słyszymy już w literaturze starotestamentalnej, od opisu gwałtownych prześladowań Żydów za Antiocha IV Epifanesa, stanowiących apokaliptyczny background dla księgi proroka Daniela ${ }^{15}$.

Pierwsze wydanie Apocalyptic Spirituality Bernarda McGinna ujrzało światło dzienne w 1979 roku, a więc jeszcze w czasach zimnej wojny i strachu przed atomową apokalipsą, która stanowiła wtedy ostatni z tych zasygnalizowanych wyżej gwałtownych kryzysów, będących właściwym środowiskiem rozwoju apokaliptycznej duchowości. Dzisiaj, po upływie kilku dekad, przybyło nowych kryzysów i ciągle mamy przed oczyma przerażający obraz zapadających się w ogniu i dymie dwóch wież Światowego Centrum Handlu, a następnie przesuwającą się przez nowojorską ulicę toksyczną chmurę, podążającą za uciekającymi przed nią ludźmi. Nie wdając się w szczegółowe analizy zjawiska apokaliptycznej duchowości na przestrzeni wieków, warto zauważyć za Bernardem McGinnem, że elementem wspólnym, występującym $\mathrm{w}$ apokaliptycznej literaturze, jest jej charakter konsolacyjny, czego najbardziej znanym i wymownym przykładem jest Janowa Apokalipsa ${ }^{16}$.

W jakim kryzysowym kontekście rodzi się wizja Joachima z Fiore? Warto poszerzyć w tym momencie tę badawczą perspektywę o inne elementy, tworzące tę formę życia duchowego, którą nazywamy duchowością religijną, a więc samą religijność, ascezę, charakterystyczny etos i wreszcie mistykę ${ }^{17}$. Źródła do biografii Joachima z Fiore ukazują go jako człowieka od młodości przejętego ideałami ewangelicznej doskonałości w ich średniowiecznym kształcie. Pielgrzymka do Ziemi Świętej, życie eremickie na zboczach Etny, konflikt z najbliższą rodziną, usiłującą wymóc na nim wejście na drogę świeckiej kariery, a następnie dość mozolny proces znajdowania sobie własnego miejsca w ramach XII-wiecznego cysterskiego monastycyzmu - to główne etapy pierwszego okresu duchowej formacji młodego Joachima $\mathrm{z}$ Fiore ${ }^{18}$. W tym czasie życie cystersów na terenie południowej Italii koncentrowało się w kalabryjskiej wspólnocie mniszej Santa Maria della Sambucina oraz w położonym w regionie Lazio opactwie w Casamari, a także w Fossanova. Wstępując do cystersów, Joachim z Fiore wszedł w żywy kontakt z duchowością

15 Zob. B. McGinn, Apocalyptic Spirituality. Treatises and Letters of Lactantius, Adso of Montier-en-Der, Joachim of Fiore, the Franciscan Spirituals, Savonarola, London 1980, s. 7-8; tenże, Visions of the End. Apocalyptic Traditions in the Middle Ages, New York 1998, s. 126-130; por. A.N. Wilder, The Rhetoric of Ancient and Modern Apocalyptic, „Interpretation” 25 (1971), s. 436-453.

16 „The observation that apocalyptic literature is a literature of consolation of those undergoing crisis, especially persecution for religious belief, is a commonplace" - B. McGinn, Apocalyptic Spirituality, s. 7.

17 Zob. S. Witek, Duchowość religijna, w: Encyklopedia katolicka, t. 4, Lublin 1989, kol. 330.

18 Zob. J. Grzeszczak, Joachim z Fiore. Średniowieczny przyczynek do teologii dziejów, Poznań 2006, s. 14-17. 
monastyczną, nawiązującą do najlepszych tradycji św. Benedykta i głoszącą, między innymi, konieczność zachowania właściwych proporcji pomiędzy życiem aktywnym i kontemplacyjnym ${ }^{19}$. Nie bez znaczenia był głoszony zwłaszcza przez św. Bernarda z Clairvaux prymat miłości, związany niewątpliwie $\mathrm{z}$ propagowanym $\mathrm{w}$ cysterskich klasztorach etosem, zakorzenionym w tradycji reformy kluniackiej. Jak pisze Stanisław Kiełtyka

W pojęciu Bernarda klasztory mają być prawdziwymi fortecami moralności chrześcijańskiej, niezłomnymi twierdzami wierności względem Kościoła i papieża, awangardą w walce o jego prawa, przykładem ubóstwa, bezinteresowności, poświęcenia, centrami czystości doktryny ewangelicznej. Działalność piśmiennicza Bernarda jest więc ściśle związana $\mathrm{z}$ ideą reformistyczną i utrwaleniem zdobyczy konkordatu wormackiego, z duchem wielkiego papieża Grzegorza VII ${ }^{20}$.

Dobrze nam znana mistyka i jej teoria w wydaniu św. Bernarda sytuuje się w tym charakterystycznym dla średniowiecza nurcie.

Dlaczego w takim razie opat $\mathrm{z}$ Fiore nie zadowolił się cysterską duchowością i od drugiej połowy lat osiemdziesiątych XII wieku zaczął się dystansować od swoich zakonnych współbraci? Jeśli weźmiemy pod uwagę fakt, że Joachim miał już wtedy około pięćdziesiąt lat, to z osobistego punktu widzenia dokonał niewątpliwie wyraźnego zerwania z przeszłością ${ }^{21}$. Miały na to wpływ wydarzenia, do jakich doszło w latach osiemdziesiątych i dziewięćdziesiątych XII wieku. Po rozgromieniu wojsk Królestwa Jerozolimskiego, dnia 2 października 1187 roku Saladyn wkroczył do Jerozolimy ${ }^{22}$. Los miasta został przypieczętowany już wcześniej, o czym dobrze wiedziała papieska kuria, a wraz z nią Joachim z Fiore. Należy w tym miejscu przypomnieć, że bardzo ważny dla ukształtowania Joachimowych poglądów pobyt w opactwie w Casamari umożliwił mu nawiązanie kontaktów ze środowiskami kurialnymi i samym papieżem, przebywającym w pobliskim Veroli. Powodem, dla którego panujący w latach 1181-1185 Lucjusz III nie był w stanie osiąść w Wiecznym Mieście, był jego ostry konflikt z dążącymi do niezależności mieszkańcami Rzymu. Ich nienawiść do kleru Ferdinand Gregorovius, XIX-wieczny niemiecki historyk średniowiecznego Rzymu określił mianem „dzikiej i barbarzyńskiej”23. Nic więc dziwnego, że papież, chcąc nie chcąc, prawie cały

19 Zob. M. Czubak Scholle, Św. Bernard z Clairvaux i początki mistyki cysterskiej, w: Przewodnik po filozofii średniowiecznej. Od św. Augustyna do Joachima z Fiore, red. A. Kijewska, Kraków 2012, s. 300.

20 S. Kiełtyka, Święty Bernard z Clairvaux, Kraków 1984, s. 90.

${ }^{21}$ Zob. G.L. Potestà, Il tempo dell'Apocalisse, s. 239.

${ }^{22}$ Zob. S. Runciman, Dzieje wypraw krzyżowych, t. 2: Królestwo Jerozolimskie i frankijski Wschód 1100-1187, tłum. J. Schwakopf, Katowice 2009, s. 397.

${ }^{23}$ F. Gregorovius, Storia della città di Roma nel Medioevo, t. 4, Brugherio-Milano 1988, s. 560. 
swój niezbyt długi pontyfikat spędził wraz ze swoim dworem w rezydencjach na terenie Państwa Kościelnego. To właśnie do Veroli kuria papieska wezwała Joachima, by zinterpretował tajemniczo brzmiącą sybillę znalezioną w bibliotece zmarłego w tym czasie w Rzymie kurialnego kardynała Mateusza z Angers $^{24}$. Nie jest wykluczone, że prawdziwym powodem wezwania opata do papieża była chęć sprawdzenia jego egzegetycznych umiejętności przed podjęciem decyzji o udzieleniu mu licentia scribendi ${ }^{25}$.

W 1184 roku papież wydał wraz z cesarzem Fryderykiem Barbarossą dekret wymierzony przeciwko katarom i waldensom, zmierzający do rozwiązania nabrzmiałego problemu szerzących się na Zachodzie herezji. Zgoda pomiędzy dwiema najwyższymi władzami ówczesnego zachodniego świata trwała jednak bardzo krótko. Gdy w 1186 roku następca Lucjusza III Urban III opowiedział się przeciwko kandydatowi na stolicę arcybiskupią w Trewirze, popieranemu przez cesarza i większość tamtejszej kapituły katedralnej, wojska cesarskie najechały i spustoszyły Państwo Kościelne. Wiadomość o upadku Jerozolimy dotarła do kurii papieskiej w Weronie, gdzie Urban III i jego współpracownicy zostali praktycznie zamknięci w obrębie miejskich murów i pozbawieni przez Barbarossę możliwości kontaktu ze sprzymierzeńcami Stolicy Apostolskiej. We wrześniu 1187 roku dotarła tam do papieża rozpaczliwa prośba o ratunek dla Ziemi Świętej, skierowana przez patriarchę Jerozolimy Herakliusza.

Ab Oriente clamat mors, ab Occidente perditio (,Ze Wschodu woła śmierć, z Zachodu zagłada") - wołał Joachim z Fiore w swoim Liście do wszystkich wiernych, streszczając w ten sposób dramatyczną sytuację, w jakiej znalazła się średniowieczna Christianitas ${ }^{26}$. Narastające zagrożenie ze strony ekspansywnego islamu, szerzące się herezje i polityka Barbarossy, brutalnie godząca w libertas Ecclesiae, będącą jednym ze sztandarowych haseł reformy gregoriańskiej, to tylko niektóre zjawiska, które musiały spędzać sen z powiek nie tylko kościelnym dostojnikom, ale i zwykłym wiernym. Jak pisze Gian Luca Potestà, „Upadek Jerozolimy stał się dla Joachima motywem do głębokich przemian ideowych: $\mathrm{z}$ jednej strony usiłował umiejscowić to wydarzenie we własnym scenariuszu czasów ostatecznych; $z$ drugiej zaś przekonał się do poglądu, że ostateczne prześladowania są znacznie bliżej, niż dotychczas uwa-

${ }^{24}$ Zob. B. McGinn, Joachim and the Sybil. An Early Work of Joachim of Fiore from Ms. 322 of the Biblioteca Antoniana in Padua, „Cîteaux. Commmentarii Cistercenses” 24 (1973), s. 129-138; M. Kaup, De prophetia ignota - Eine frühe Schrift Joachims of Fiore, MGH, Studien und Texte, 19, Hannover 1998, s. 180-224; Gioacchino da Fiore, Commento a una profezia ignota, Opere di Gioacchino da Fiore: Testi e Strumenti, 10, red. M. Kaup, Roma 1999, s. 151-181.

${ }^{25}$ Zob. J. Grzeszczak, Chwila jest bliska. Wizje końca w literaturze profetycznej (XII-XX wiek), Poznań 2011, s. 41.

26 Joachim z Fiore, List do wszystkich wiernych, thum. M. Beściak, D. Budzanowska, „Kronos. Metafizyka, Kultura, Religia” 29 (2014), nr 2, s. 82. 
żał"27. Warto przypomnieć, że przypadające na lata osiemdziesiąte XII wieku Joachimowe studium obejmuje intensywną refleksję nad Janową Apokalipsą oraz popularną w średniowieczu problematyką Antychrysta ${ }^{28}$. To właśnie wtedy nabiera u Joachima kształtów przerażająca idea Antychrysta, który zasiądzie na papieskim tronie, a także ewentualność wymierzonego w Kościół sojuszu „Bestii wychodzącej z morza”, czyli muzułmanów, z „Bestią wychodzącą z ziemi", czyli zachodnich heretyków ${ }^{29}$.

W tej sytuacji gorliwym mnichom nie pozostawało nic innego, jak dać posłuch Chrystusowemu wezwaniu z Ewangelii według św. Mateusza: „Gdy więc ujrzycie «ohydę spustoszenia», o której mówi prorok Daniel, zalegającą miejsce święte - kto czyta, niech rozumie - wtedy ci, którzy będą w Judei, niech uciekają w góry"30. Joachim z Fiore przekonuje się też ostatecznie, że w obliczu nadchodzącej apokalipsy piękna cysterska duchowość jest zbyt soft i nie będzie w stanie sprostać dziejowej burzy. Ilustracją tego przekonania niech będzie ciekawy przykład Joachimowej egzegezy tekstu niebiblijnego, jakim są Dialogi św. Grzegorza Wielkiego ${ }^{31}$. W swojej apokaliptycznej egzegezie opat z Fiore sięga do znanego nam, być może, epizodu z życia św. Benedykta, opisanego przez Grzegorza Wielkiego, a mianowicie do wzruszającego spotkania z siostrą: „Jego siostra, Scholastyka, wszechmogącemu Panu poświęcona już od najwcześniejszego dzieciństwa, zwykła raz na rok brata odwiedzać. Mąż Boży schodził do niej i przyjmował ją niezbyt daleko za bramą budynku należącego do klasztoru"32. Sam Benedykt, który już wcześniej opuścił Subiaco i udał się na górę obok miasta Cassino, aby tam prowadzić życie kontemplacyjne, teraz schodzi, aby spotkać się z siostrą. Jeśli umieścimy ten epizod w szerszym kontekście apokaliptycznej egzegezy Joachima z Fiore, w której św. Scholastyka jawi się jako obraz zakonu cysterskiego, to łatwo możemy sobie zdać sprawę z miejsca, jakie cystersi zajmują w wypracowanej przez opata wizji dziejów. „Tak więc - pisze Joachim - św. Scholastyka oznacza całą wspólnotę cysterską, która, chociaż święta i niewinna, to jednak jak słaba kobieta, nie jest w stanie wejść na tak strome górskie wzniesienia"33.

27 G.L. Potestà, Il tempo dell'Apocalisse, s. 159.

${ }^{28}$ Zob. B. McGinn, Antychryst. Dwa tysiace lat fascynacji człowieka złem, tłum. B. Cendrowska, Warszawa 1998, s. 185-194.

${ }^{29}$ Zob. 2 Tes 2,3-4; Ap 13, 1, 11.

${ }^{30}$ Mt 24,15-16; por. 1 Mch 1,54; Dn 9,27.

31 Zob. Grzegorz Wielki, Dialogi, tłum. E. Czerny, A. Świderkówna, Kraków 2007.

${ }^{32}$ Zob. tamże, s. 191.

33 Igitur in beata Scolastica Cisterciensium unanimitas designatur, que licet sancta et innocens, ut imbecillis tamen femina ardua montis scandere et tam arta nequivit - Ioachim Abbas Florensis, Tractatus in expositionem vite et regule beati Benedicti cum appendice fragmenti (I) de duobus prophetis in novissimis diebus praedicaturis, Fonti per la storia dell'Italia medievale, Antiquitates, 29, red. A. Patschovsky, Roma 2008, s. 180. 


\section{Doświadczenia w Casamari i ich mistyczne konotacje}

Przejdźmy teraz do drugiej i ostatniej części naszej refleksji, a mianowicie próby odpowiedzi na pytanie o mistykę u Joachima z Fiore. Kalabryjski opat jest niewątpliwie człowiekiem ceniącym sobie nade wszystko kontemplację i szukającym do niej warunków, a więc ciszy i samotności. Przywołany wyżej epizod ze św. Scholastyką w roli głównej, odzwierciedla trudności, na jakie napotykali cystersi w realizacji tego ideału. Joachim, który zna ich sytuację niejako od wewnątrz, stwierdza:

Boży człowiek, Benedykt, został zmuszony przez miłość [jaką żywił do swojej siostry] zejść do niej, podobnie jak ci, którzy w zakonie mogliby znaleźć się wyżej i rzeczywiście zaczynają tak żyć, ale są zmuszeni ze względu na słabych współbraci zrezygnować z własnej gorliwości i wyjść naprzeciw tym, którzy stoją na dole, a kierując się miłością ku słabym, są także zmuszeni do wspólnego $\mathrm{z}$ nimi nocowania, choć nie czynią tego chętnie ${ }^{34}$.

Zgodnie z obowiązującymi w zakonie cystersów zasadami, każdy dom powinien poprzez afiliację stać się częścią wielkiej rodziny zakonnej. Szukając możliwości afiliacji wspólnoty w kalabryjskim Corazzo, Joachim udał się do Casamari, gdzie przebywał około półtora roku, w latach 1183-1184. Choć próba afiliacji Corazzo do opactwa w Casamari zakończyła się niepowodzeniem, to dla Joachima czas spędzony w tamtejszej wspólnocie był momentem przełomowym. To w Casamari mógł poświęcić się modlitewnej kontemplacji, ubogacił swoją wiedzę teologiczną w klasztornej bibliotece, spotkał się z osobami z głównego nurtu życia i działalności Stolicy Apostolskiej. Tam też redagował swoje główne dzieła.

W Casamari Joachim przeżył również dwa wydarzenia, które dość obszernie relacjonuje na kartach swoich głównych dzieł. W Wykładzie Apokalipsy opat z Fiore wspomina o ogromnych trudnościach interpretacyjnych, jakie napotkał $\mathrm{w}$ momencie, gdy doszedł do 10. wiersza pierwszego rozdziału: „Doznałem zachwycenia w dzień Pański”. Chcąc nie chcąc, musiał pogodzić się z tym stanem rzeczy, opuścił ten trudny fragment i kontynuował komentowanie dalszych części Apokalipsy. Nieoczekiwany przełom nastąpił w noc paschalną, kiedy Joachim doświadczył swego rodzaju intuicji: „Ukazała się oczom mojego umysłu pełnia tej księgi oraz cała zgodność Starego i Nowego Testamentu" 35 . Kiedy po tym wydarzeniu wrócił do sprawiającego mu ogromne trudności fragmentu Apokalipsy, natychmiast wyszedł z egzegetycznego impasu. Podobny charakter miało wydarzenie, o którym dowiadu-

\footnotetext{
${ }^{34}$ Ioachim Abbas Florensis, Tractatus in expositionem vite..., s. 180-181.

35 Zob. Expositio magni prophete Abbatis Ioachim in Apocalipsim [...] Venetiis 1527, f. 39c.
} 
jemy się z relacji, jaką pozostawił na kartach swojego Psalterium o dziesięciu strunach (Psalterium decem cordarum). Joachim opisuje swój stan ducha w kategoriach przewlekłego kryzysu, na który miały wpływ także czynniki zewnętrzne w postaci zajęć administracyjnych, które rozpraszały jego umysł i odciągały od umiłowanej kontemplacji. Uroczystość Zesłania Ducha Świętego opat z Fiore odczytał jako dobry moment, by pomodlić się o dar mądrości, potrzebny mu do zgłębiania treści ukrytych w Piśmie Świętym: „Miałem [...] nadzieję, że w ten dzień otrzymam coś od Tego, który daje wszystkim chętnie $i$ nie wymawiajac" ${ }^{36}$. Niestety, zamiast obiecanych darów duchowych, niespodziewanie pojawiło się paraliżujące mnicha zwątpienie w dogmat o Bogu Jedynym w Trzech Osobach. Chcąc pokonać uczucie strachu, opat szuka schronienia $\mathrm{w}$ przewidzianej na tę uroczystość modlitwie psalmami. W jej trakcie doświadcza intuicji, która wywarła ogromny wpływ na jego dalszą twórczość:

Nagle ujrzałem w duchu kształt psalterium o dziesięciu strunach, a w kształcie tym ukazała mi się tajemnica Trójcy Świętej tak jasno i otwarcie, że zaraz musiałem zawołać: który bóg dorówna wielkościa naszemu Bogu? Ty jesteś Bogiem dziatajacym cuda (Ps 77,14-15) oraz Pan nasz jest wielki i zasobny w sity, madrość Jego jest niewypowiedziana (Ps 147,5) ${ }^{37}$.

Spróbujmy najpierw wydobyć z tych dwóch narracji wspólną im sekwencję zdarzeń. Wiele razy już wspominano, że pragnieniem Joachima z Fiore była kontemplacja, rozumiana przede wszystkim w aspekcie poznawczym jako przeniknięcie poza zasłonę kryjącą całość dziejowych procesów. Aby tego dokonać, należy koniecznie wyjść poza literę i dotrzeć do duchowego znaczenia poznawanej rzeczywistości. Joachim z Fiore kładzie nacisk na stopniowy proces odsłaniania się przed człowiekiem duchowych znaczeń. W jednym z kazań, rozpoczynającym się od słów Apocalipsis liber ultimus, opat z Fiore roztacza przed słuchaczami obrazy zaczerpnięte z przyrody i nawiązuje do zmartwychwstania Chrystusa:

Jeśli chcemy przystąpić do słodyczy miąższu, najpierw jest konieczne, aby zdjąć zewnętrzną łupinę, następnie osłonę i wreszcie przystąpić do wnętrza. Tak właśnie tajemnica, którą chcemy tu rozważać, okryta jest jakby wełnianą oraz lnianą szatą. Pod nimi jako trzecie kryje się żywe ciało, którego poszukujemy. Gdy zdjęta zostanie tunika, odsłoni się lniana szata, a gdy ona zostanie zdjęta, ukaże się ciało. Gdy odsunięto głaz, ukazała się lniana szata Chrystusa; gdy opadła szata, Chrystus wyszedł żywy. A głaz został odsunięty, by odsłonić tę tajemnicę, która

36 Zob. Joachim z Fiore, Psalterium o dziesięciu strunach, tłum. M. Beściak, „Kronos. Metafizyka, Kultura, Religia", 29 (2014), nr 2, s. 62.

37 Tamże. 
zawiera w sobie wszystkie inne. Lniana szata opadła, aby umożliwić dostęp do drugiego rodzaju tajemnic, które zawarte były pod pieczęcią - a Chrystus, który sam jest Prawdą, oznacza tu poznanie duchowe ${ }^{38}$.

Oczywiście pierwszym rozwiązaniem, jakie rozum podsuwa nam w tym przypadku, byłoby sięgnięcie po księgi i intensywne studium. W Psalterium o dziesięciu strunach Joachim wspomina, że próbował skorzystać z możliwości, jaką stwarza exercitium lectionis: „Niegdyś i ja także byłem niespokojny o Słowo Pańskie i usiłowałem przez badanie ksiąg dojść do poznania prawdy"39. Okazało się jednak, że upragniona notitia veritatis oddalała się coraz bardziej, rodząc $\mathrm{w}$ sercu mnicha pogłębiającą się frustrację. Lekarstwem na tę ostatnią jest psalmodia. George Tovard w przywołanym na początku tego artykułu fragmencie wykluczył funkcjonalne pokrewieństwo Joachimowych figur z dalekowschodnią mandalą, otwierającą oczy na niedostrzegalne dotąd perspektywy. Wydaje się, że miał rację, ale nie dlatego, że figury miałyby do odegrania rolę podobną do tej, jaką odgrywa mandala, ale dlatego, że podobieństwo - o ile istnieje - zachodzi pomiędzy mandalą i psalmodią. Mandala jest praktyką pomagającą w odnalezieniu samego siebie i medytowaniu tego, co transcendentne ${ }^{40}$.

Pochwała psalmodii, jaką znajdujemy w Joachimowym Psalterium o dziesięciu strunach, kładzie akcent na dobroczynny wpływ recytacji psalmów nie tylko na ludzką duszę, która oddaje chwałę Bogu, ale także na spotęgowanie możliwości poznawczych człowieka w tym, co dotyczy wiedzy tradycyjnie określanej mianem metafizycznej, która to wiedza przekłada się na żywą relację z Bogiem. Przykładem tej ostatniej był psalmista Dawid i stąd to właśnie on staje się dla Joachima z Fiore depozytariuszem klucza otwierającego drzwi do mądrości. Wydaje się, że w ten sposób kalabryjski opat wyraża to samo, co teoria mistyki mówi na temat oczyszczenia serca, które poprzedza jakiekolwiek doświadczenie mistyczne.

Niespodziewana wątpliwość, jaka naszła Joachima z Fiore w oratorium, zasługuje na nieco więcej uwagi:

[...] gdy wszedłem do oratorium i pokłoniłem się Bogu Wszechmogącemu przed świętym ołtarzem, naszła mnie pewna wątpliwość, dotycząca tajemnicy Trójcy Świętej. Jest rzeczą trudną - myślałem sobie - zarówno dla rozumu, jak i dla wiary, że trzy Osoby są jednym Bogiem, a jeden Bóg jest w trzech Osobach.

38 Joachim z Fiore, Wprowadzenie do Apokalipsy, thum. P. Grad, „Kronos. Metafizyka, Kultura, Religia" 29 (2014), nr 2, s. 45.

39 Zob. tenże, Psalterium o dziesięciu strunach, s. 61.

40 Zob. T.R. Chopra, Mandala, w: Nuovo Dizionario delle religioni, red. H. Waldenfels, Cinisello Balsamo (Milano) 1993, s. 536. 
Gdy naszła mnie ta wątpliwość, zląkłem się wielce i ze strachu musiałem wzywać Ducha Świętego, którego święto przypadało tego dnia, prosząc Go, by zechciał mi objawić świętą tajemnicę Trójcy Świętej, bo w Nim właśnie obiecał nam Pan poznanie całej prawdy ${ }^{41}$.

Ten ciekawy epizod przywołuje na myśl twórczość irlandzkiego pisarza i poety Williama Butlera Yeatsa (1865-1939), rozmiłowanego w alchemii, ezoteryzmie i teozofii laureata Literackiej Nagrody Nobla, wykorzystującego w swojej twórczości wątki zaczerpnięte z Joachimowej tradycji ${ }^{42}$. Jednak w przeciwieństwie do ekscentrycznych bohaterów opowiadań Yeatsa, Joachim z Fiore przezwycięża natychmiast pokusę, a silne uczucie strachu przynagla go do modlitewnego zwrócenia się o pomoc do Ducha Świętego. Jak pisze Beatrice Hirsch-Reich

Klucz do wizji psalterium leży w umartwieniu własnych pragnień i zapanowaniu nad emocjami, tak, by zmusić samego siebie do wykonania czynności, jaką było wyrecytowanie przewidzianej liczby psalmów. [Podjęty przez Joachima] wysiłek samodyscypliny rozjaśnił jego umysł tak, by mógł rzeczywiście otrzymać napełnienie wyższego rzędu wiedzą w postaci obrazu, który przyniósł mu rozwiązanie przeżywanych trudności i sprawił, że mógł wybuchnąć słowami najgłębszej adoracji. Objawienie w formie błysku jest charakterystyczną cechą tego rodzaju duchowego doświadczenia ${ }^{43}$.

Autorka zwraca też uwagę na fakt, że opisane przez Joachima doświadczenie zostało przez niego zinterpretowane nie jako owoc silnego pragnienia, ale jako wewnętrzne przeżycie o charakterze nadprzyrodzonym, po którym nastąpił czas wyjątkowej płodności intelektualnej, o czym zaświadcza jego przyjaciel i dziejopis Łukasz z Cosenzy: „Siedząc u jego stóp bądź na terenie klasztoru, bądź też w spichlerzu w pobliskim Sant'Angelo in Corneto, posłusznie i pokornie dzień i noc zapisywałem w zeszycie to, co on sam dyktował i poprawiał na kartkach, razem z bratem Janem i bratem Mikołajem, dwoma mnichami, którzy byli jego skrybami" ${ }^{4}$. Figury, od których rozpoczął się niniejszy tekst, a zwłaszcza trapez z okręgiem wewnątrz, nawiązujący kształtem do

41 Joachim z Fiore, Psalterium o dziesięciu strunach, s. 62.

${ }^{42}$ Zob. W. Gould, M. Reeves, Joachim of Fiore and the Myth of the Eternal Evangel, rozdz. IX: W.B. Yeats: A Noble Antinomianism, s. 221-298; J. Grzeszczak, Dall'Età dello Spirito Santo al New Age. Gioacchino da Fiore nella nuova religiosità, Poznań 2008, s. 163-182.

${ }_{43}$ M. Reeves, B. Hirsch-Reich, The Figurae of Joachim of Fiore, Oxford 1972, s. 53.

44 „Joachim did not regard his experience as brought about by his own conscious will. For him it was of a supernatural nature, stirring the depths of his soul" - tamże; zob. H. Grundmann, Per la biografia di Gioacchino da Fiore e di Raniero da Ponza, w: tenże, Gioacchino da Fiore. Vita e opera, Opere di Gioacchino da Fiore: testi e strumenti, 8, Roma 1997, s. 191-192. 
instrumentu muzycznego - psalterium o 10 strunach, stają się przedmiotem szczegółowych analiz i wyliczeń, które sam Joachim nazywa „duchową arytmetyką" (arithmetica spiritualis) ${ }^{45}$. Choć mamy tu do czynienia z intensywną pracą intelektu kalabryjskiego opata, który jako wytrawny hermeneuta wydobywa ze skorupy litery pożywny i smaczny owoc duchowego rozumienia Bożego słowa, to jednak nie należy zapominać, że u początków swojej imponującej pracy egzegetycznej został przynaglony (conterritus) do psalmodii i medytacji ${ }^{46}$. Wzajemne przenikanie się intelektu i elementów, będących owocem doświadczenia o charakterze mistycznym, stanowi specyficzną cechę Joachimowej twórczości.

Mając na uwadze nakreśloną wyżej charakterystykę pisarstwa Joachima z Fiore, trudno nie przyznać racji Beatrice Hirsch-Reich, która nazywa go „kalabryjskim mistykiem”, a dziesięciostrunne psalterium określa mianem „najbardziej mistycznej z Joachimowych figur" ${ }^{47}$. Mając na uwadze postawione w tym artykule cele, nie sposób nie wydobyć na światło dzienne tych jedynych w swoim rodzaju cech Joachimowej spuścizny. Interesujący nas okres średniowiecza wraz z wizjonerką Hildegardą z Bingen, która, chcąc wyjaśnić mysteria secretorum Dei, odżegnuje się od naukowości i sięga po udzielony jej prorocki charyzmat, jest jeszcze czasem dominacji kultury monastycznej, w której obraz odgrywa niezwykle ważną rolę w przekazie treści składających się na ówczesną duchowość, zwłaszcza apokaliptyczną ${ }^{48}$. Dotykamy w tym momencie zagadnienia niezwykle złożonego i wymagającego studium o charakterze interdyscyplinarnym z udziałem specjalistów z dziedziny cywilizacji średniowiecznej w jej różnych przejawach ${ }^{49}$. Sam Joachim wypracował własny słownik terminów, oddających zarysowany wyżej na przykładzie dziesięciostrunnego psalterium proces ukazywania za pomocą obrazu tego, co widzi wewnętrzna intuicja ${ }^{50}$. W jego spuściźnie znaleźć można takie wyrażenia, jak

45 Zob. Ioachim Abbas Florensis, Enchiridion super Apocalypsim, w: Gioacchino da Fiore sull'Apocalisse, red. A. Tagliapietra, Milano 1994, s. 306.

46 Zob. M. Reeves, B. Hirsch-Reich, The Figurae of Joachim of Fiore, s. 53-54.

47 „The Psaltery with ten strings is the most mystical of Joachim's figures. It is based on a vision from which sprang his third work [Psalterium decem cordarum - J.G.]. No other figure was introduced so elaboratery by the mystic of Calabria nor in sucha an exalted state of mind" - tamże, s. 51.

${ }^{48}$ Zob. J. Łukaszewska-Haberkowa, Wstęp, w: Hildegarda z Bingen, Wizje, czyli poznaj drogi Pana, Kraków 2011, s. 11.

49 Zob. tylko niektóre klasyczne monografie uznanych autorów, mogące odegrać rolę wprowadzeń do interesującego nas zagadnienia: J. Le Goff, Kultura średniowiecznej Europy, thum. H. Szumańska-Grossowa, Gdańsk-Warszawa 2002; tenże, Czasy katedr. Sztuka i społeczeństwo 980-1420, tłum. K. Dolatowska, Warszawa 2002; A. Vauchez, Duchowość średniowiecza, thum. H. Zaremska, Gdańsk 2004; M.M. Davy, Initiation à la symbolique romane (XII siècle), Paris 1977.

50 Zob. F. Troncarelli, Interior acies. Immagine e intuizione in Gioacchino da Fiore, „Florensia. Bollettino del Centro Internazionale di Studi Gioachimiti” 16-17 (2002-2003), s. 89. 
„wzrok wewnętrzny” (interior acies) czy „duchowe oczy umysłu” (spiritales mentis oculi), które odsyłają do poznania o charakterze nie tylko intelektualnym, lecz również mistycznych intuicji. Wczesne średniowiecze oferowało niezwykle bogaty zasób figur, które zaludniały wyobraźnię ówczesnych ludzi, zwłaszcza mnichów, i mogły odegrać rolę podobną do tej, jaką odegrało dziesięciostrunne psalterium w przezwyciężeniu przez Joachima wątpliwości związanych z dogmatem trynitarnym.

Nie należy jednak zapominać o tym, że myślenie za pomocą figur, łączące w sobie rozumowanie i mistyczną intuicję, obciążone było niejedną słabością ${ }^{51}$. W czasach Joachima ten sposób poznania rzeczywistości odchodził w przeszłość wraz z kulturą monastyczną, która ustępowała miejsca uniwersytetom. Hipoteza, jaką podaje Fabio Troncarelli, wydaje się w tym kontekście jak najbardziej trafna: ,[...] gdyby [Joachim - J.G.] wybrał drogę wyznaczoną przez logikę, zostałby nieuchronnie wciągnięty przez wir odkrycia Arystotelesa, scholastycznej logiki, która wyraźnie zrywa z dotychczasową tradycją"52. To jednak, co nie nastąpiło za jego życia, dotknęło spuściznę tego XII-wiecznego autora kilkadziesiąt lat po jego śmierci. W 1255 roku Stolica Apostolska zabrała głos w sprawie Joachimowych figur. Rok wcześniej poruszenie środowisku paryskiego uniwersytetu wywołał traktat Gerarda z Borgo San Donnino. Ten franciszkański radykał zapowiadał na rok 1260 nadejście nowego chrześcijaństwa, a także zastąpienie Starego i Nowego Testamentu nowym orędziem, wieczystą ewangelią, w której skład wejdą pisma Joachima z Fiore. Przekonanie o rychłym nadejściu nowych czasów zawarł w swoim traktacie, znanym jako Introductorius in Evangelium aeternum, który spotkał się z szybką reakcją Kościoła. Dla zbadania jego zawartości papież Aleksander IV zwołał specjalną komisję, w skład której weszli, między innymi, dwaj biegli w teologii francuscy kardynałowie: Odo z Châteauroux i Hugo z Saint-Cher, związani z uniwersytetem paryskim.

Komisja, obradująca w podrzymskim Anagni, zajęła się kompleksowo problemem wieczystej ewangelii Gerarda z Borgo San Donnino. W tym celu przeanalizowała również dzieła samego Joachima, a rezultaty prac i opinię na temat zbadanych doktryn przedstawiła w piśmie, znanym jako „Protokół z Anagni”, które w 1885 roku doczekało się wydania drukiem i stanowi cen-

${ }^{51} \mathrm{Na}$ temat roli i wymowy figur w spuściźnie Joachima z Fiore - zob. Die Bildwelt der Diagramme Joachims von Fiore. Zur Medialität religiös-politischer Programme im Mittelalter, red. A. Patschovsky, Ostfildern 2003; M. Rainini, Disegni dei tempi. Il „Liber Figurarum” e la teologia figurativa di Gioacchino da Fiore, Opere di Gioacchino da Fiore: testi e strumenti, 18, Roma 2006; Pensare per figure. Diagrammi e symboli in Gioacchino da Fiore. Atti del $7^{\circ}$ Congresso internazionale di studi gioachimiti, San Giovanni in Fiore - 24-26 settembre 2009, Opere di Gioacchino da Fiore: Testi e Strumenti, 23, red. A. Ghisalberti, Roma 2010.

52 F. Troncarelli, Interior acies, s. 93. 
ne, ponieważ powstałe przeszło 50 lat po śmierci opata z Fiore, opracowanie jego doktryny ${ }^{53}$. Po zapoznaniu się z zawartością Joachimowych dzieł papiescy teologowie stwierdzili w konkluzji, że zawierają one „bardzo wiele rzeczy dziwnych, niepotrzebnych i niezręcznych" (plurima curiosa, inutilia et inep$t a$ ), a należy do nich figura nawiązująca do kształtu instrumentu muzycznego - dziesięciostrunnego psalterium ${ }^{54}$. Obojętni na mistyczne intuicje kalabryjskiego opata, rzymscy purpuraci chłodnym i wnikliwym wzrokiem ogarnęli zarówno samą figurę, jak i przypisane jej przez Joachima znaczenie. Skoncentrowałi się na szczegółach, w których dostrzegli błędy Joachimowego myślenia i pomijanie przez opata oczywistych faktów: nie można się z nimi nie zgodzić, że trapezoidalny kształt psalterium sprawia, że w rzeczywistości mamy do czynienia nie z trzema, lecz czterema narożnikami, co stoi w sprzeczności $\mathrm{z}$ dogmatem trynitarnym ${ }^{55}$. Nie pominęli też faktu, że sam Joachim, świadomy rzucających się w oczy różnic pomiędzy górnym narożnikiem psalterium i dwoma dolnymi, wykorzystał mimo to ten szczegół jako punkt wyjścia do dalszej refleksji na temat Osób Trójcy Świętej ${ }^{56}$.

Krytyczny wywód papieskich teologów zamyka uwaga o charakterze metafizycznym, będąca znakiem nowych tendencji, widocznych w teologii uprawianej na uniwersytetach. W Joachimowym uciekaniu się do figur ujrzeli oni ewidentną sprzeczność, kalabryjski opat wykazał się - ich zdaniem - tępotą myślenia, przypisując wiecznym zasadom cechy przysługujące ograniczonym figurom (obtusio seu hebetudo figure), podczas gdy cała filozofia uczy, że im bardziej coś ma charakter wiecznej zasady, tym więcej prostoty mu przysługuje $^{57}$.

${ }^{53}$ Zob. H. Denifle, Das Evangelium aeternum und die Commission zu Anagni, „Archiv für Literatur und Kirchengeschichte des Mittelalters" 1 (1885), s. 97-142.

54 Zob. tamże, s. 140.

${ }^{55}$ Hec extracta sunt de libris Joachim, que satis possunt sufficere ad cognoscendum de doctrina ejus, que quamvis preter ista contineantur in eis plurima curiosa, inutilia et inepta ad ea propter que inducit ea ipse Joachim, sicut est illud de tribus cornibus psalterii musici decacordi, per quod intendit astruere fidem trinitatis aproprians illud cornu, scilicet angulum obtusum, persone patris, reliquos autem duos angulos acutos filio et spiritui sancto, quamvis iste angulus obtusus non sit angulus unus, sed pocius duo, sicut patet intuenti: nichilominus tamen accipit illos duos angulos, pro uno, aproprians illum patri $[\ldots]$ - tamże.

${ }^{56}$ Zob. tamże, s. 140-142.

57 Nota quod contrarie sunt rationes iste veritati, ut scilicet ei attribuatur obtusio seu hebetudo figure, cui primo debetur ratio principii et eternitatis, et acumen ei non competat, cum tamen omnis philosophia dictet, quod quanto plus habet aliquid ratione principii et eterni, tanto plus conveniat ei ratio simplicitatis in omni re de mundo. Principia enim simpliciora sunt in suo genere - tamże, s. 142. 


\section{Podsumowanie}

Fenomen Joachima z Fiore należy rozpatrywać przede wszystkim w kontekście czasów, w których ten kalabryjski opat żył i tworzył. Jego apokaliptyczna duchowość żywiła się wytrwałą medytacją treści biblijnego objawienia, która uczyniła Joachima jednym z wielkich średniowiecznych egzegetów. Twórczość Joachima z Fiore sprowadza się do wieloletniej scrutatio Scripturarum, której owocem są zwłaszcza trzy główne dzieła: Concordia Novi ac Veteris Testamenti, Expositio in Apocalypsim i Psalterium decem cordarum. Niespokojne czasy, w których przyszło mu żyć, miały niebagatelny wpływ na kształt jego refleksji, mającej za punkt wyjścia dogmat trynitarny oraz ideę zgodności (concordia) Starego i Nowego Testamentu.

Wydaje się, że ten splot czynników należy wziąć pod uwagę przy próbie oceny Joachimowej mistyki, którą dostrzec można w pozostawionych przez tego autora opisach dwóch intuicji, odgrywających kluczową rolę $\mathrm{w}$ procesie formowania się jego pełnej rozmachu teologicznej wizji dziejów. Mistyka Joachima z Fiore jest osadzona w XII-wiecznej tradycji teologicznego przekazu, w którym istotne zadanie do spełnienia ma czynnik wizualny. Joachimowa mistyka prowadzi do rozumienia (intelligentia), otwierającego się przed hermeneutą w sposób nagły i poprzedzonego elementami, które można spotkać w teorii doświadczenia mistycznego, widocznej w refleksji współczesnych Joachimowi środowisk monastycznych.

\section{ANEKS}

\section{Intuicja paschalna (Expositio in Apocalypsim, I, 13)}

Ten fragment (Ap 1,10) jest bardzo ważny i znajduje się wewnątrz głębokiej symboliki. Dyskurs jest prosty, ale nie tajemnica; skorupa jest widoczna, ale ziarno pozostaje ukryte. Mówi: „Doznałem zachwycenia w dzień Pański”. Co oznaczają Janowe słowa: „Doznałem zachwycenia [...]”? Co oznacza dalsze wyrażenie: „[...] w dzień Pański”? Być może dla niektórych było to coś dostępnego i łatwego do zrozumienia; ja natomiast, kiedy po raz pierwszy zetknąłem się z tym fragmentem, znalazłem się jakby w morskiej topieli, a stało się tak, ponieważ Bóg zwykł rozjaśnić jednemu to, co drugiemu wydaje się ciemne, aby w ten sposób każdy nauczył się nie szukać głębokości poznania, ale poprzestawania na wiedzy właściwej pokornym (por. Rz 12,16). Tak więc, kiedy po lekturze poprzednich części tej księgi doszedłem do tego fragmentu, wyznaję, że znalazłem się w obliczu tak wielkiej trudności i w sposób nadzwyczajny stanęły na mojej drodze przeszkody w zrozumieniu, że, czu- 
jąc jakby grobowy kamień, który zamykał mi drogę do wnętrza, stałem się jak otępiały. Oddając więc chwałę Bogu, który według swojego upodobania zamyka i otwiera, pominąłem ten fragment i poszedłem dalej, pozostawiając rozwiązanie tej trudności Nauczycielowi wszystkich, aby Ten, który otworzył księgę i złamał jej siedem pieczęci w czasie Jemu dogodnym, pozwolił zrozumieć mnie samemu i innym.

Kiedy, zajęty innymi rzeczami, zapomniałem o tym problemie, zdarzyło się, że po upływie roku nadeszła Wielkanoc. Z nastaniem dnia, budząc się ze snu, odniosłem wrażenie, że uchwyciłem jakąś myśl podczas medytacji tej księgi. Tak więc, ufając Panu, stałem się bardziej śmiały w pisaniu i nieskory do milczenia, i odłożenia pióra, aby przypadkiem do mnie, milczącego, nie zostały skierowane słowa sędziego: „Sługo zły i gnuśny! Wiedziałeś, że chcę żąć tam, gdzie nie posiałem, i zbierać tam, gdziem nie rozsypał. Powinieneś więc był oddać moje pieniądze bankierom, a ja po powrocie byłbym z zyskiem odebrał swoją własność" (Mt 25,26-27). I tak, kiedy zrozumiałem już pewne znaczenia, a nie pojąłem głębszych tajemnic, w moim umyśle toczyła się jakby walka: myśli, które były jasne, zachęcały do odwagi, natomiast pozostałe zapowiadały trudności.

Kiedy więc w noc paschalną przydarzyło mi się coś podobnego, w połowie nocnej ciszy - jak sądzę - i w godzinie, kiedy, jak się uważa, nasz Lew z pokolenia Judy powstał z martwych, nagle, kiedy medytowałem, ukazała się oczom mojego umysłu pełnia tej księgi oraz cała zgodność Starego i Nowego Testamentu. Nie pamiętałem o fragmencie, który mnie nurtował, nie myślałem też o tym, dlaczego Jan powiedział: „Doznałem zachwycenia w dzień Pański”, ani też, czy nieprzypadkowo wspomniane jest, że samo objawienie tej księgi miało miejsce w dniu Pańskim. Twierdzę, że nie dotarło do mnie ani to, że Chrystus wychodzący z grobu oznacza ducha uwalniającego się z litery, ani też to, że siedem dni wielkanocnego tygodnia, wraz z ósmym następującym po nich zgodne są symbolicznie z częściami tej księgi, ani też wreszcie, że w tym dniu oświecił ich umysły, aby rozumieli Pisma (por. Łk 24,45). Gdy zatem, po pewnym czasie, wykorzystałem sposobność i wróciłem do lektury tego, co dotychczas dostrzegałem powierzchownie, doszedłem do fragmentu, w którym jest mowa: „Doznałem zachwycenia w dzień Pański”; wtedy też po raz pierwszy zrozumiałem ukryte znaczenie słów Jana: „Doznałem zachwycenia w dzień Pański”; myślałem też w moim sercu o tych rzeczach, które się wydarzyły, czy też o tych, które zostały zapisane i dotyczyły tego dnia, i myślałem że stamtąd bierze początek budzący się z litery duch, a także o wielu innych rzeczach, których streszczanie trwałoby zbyt długo.

tłum. J. Grzeszczak

Oryginał łaciński: Expositio magni prophete Abbatis Ioachim in Apocalipsim [...] Venetiis 1527, f. $39 \mathrm{bc}$. 


\section{Psalterium o dziesięciu strunach (Psalterium decem cordarum - Prefatio)}

Starożytna tradycja ojców przekazała nam, współczesnym, że psalmodia jest czymś bardzo cennym i że do niej odnoszą się owe słowa psalmu: ofiara chwały uczci mię: i tam droga, która mu okażę zbawienie Boże (Ps 50,23). Wielu z tych, którzy szukają mądrości, oddało się z zapałem lekturze i zgłębianiu nauki; nie mogli jednak dotrzeć do samej istoty mądrości, ponieważ usiłowali wejść nie przez łaskę, ale przez swój wolny osąd, ten zaś od początku nie był pomocny dla tych, którzy na nim polegają. Nie znaleźli bowiem klucza Dawidowego (por. Ap 3,7), tego, który otwiera drzwi przed miłującymi mądrość. Krocząc tedy dokoła po omacku, nie potrafili znaleźć wejścia, zgodnie ze słowami Apostoła: zawsze się ucza, a nigdy nie moga dojść do poznania prawdy (2 Tm 3,7). Jakeśmy to słyszeli, tak i zobaczyli, a wszystko to potwierdzamy, bo przekonaliśmy się z doświadczenia, że się nie mylimy.

Niegdyś i ja także byłem niespokojny o Słowo Pańskie i usiłowałem przez badanie ksiąg dojść do poznania prawdy. Gdym się tak zapalał, by dzięki wytężonej lekturze jak najspieszniej ją osiągnąć, wówczas ona, przybrawszy sobie skrzydła jak orzeł (por. Iz 40,31; Prz 23,5), odstępowała ode mnie jeszcze dalej, niż była dotąd. Kiedy jednak odzyskałem świeży zapał i przez wzgląd na Pana umiłowałem psalmodię, oto wiele niejasnych miejsc w Piśmie, których przedtem nie mogłem pojąć, czytając, teraz poczęło otwierać się przede mną w cichej melodii psalmów. Nie dość na tym, bo już wtedy zacząłem także rozumieć, co znaczą słowa innego psalmu: szczęśliwi, którzy mieszkają $w$ domu Twoim, Panie, nieustannie Cię wychwalaja (Ps 84,5).

Zdawało się już, że myślami i pragnieniem stałem się mieszkańcem owego górnego miasta i że w swym wnętrzu mogłem cieszyć się wspaniałym widzeniem pokoju. Wtedy jednak przytrafiło mi się to, na co wielu na próżno się skarży: musiałem mianowicie na nowo, w trosce o majątek klasztoru, wdać się w sprawy, które nazwać trzeba albo zupełnie świeckimi, albo przynajmniej niemal świeckimi. Przeto z jękiem serca i nie bez trwogi zmuszony byłem zawołać: biada mi, że się mieszkanie moje przedłużyło: mieszkałem z mieszkańcami Cedar (Ps 120,5). Dlugo przebywała dusza moja z tymi, którzy nienawidza pokoju (Ps 120,5-6), a także: przecięty jest jako przez tkacza żywot mój; gdy jeszcze zaczynat, przeciąt mnie (Iz 38,12). Takimi więc jękami wypełnione były myśli moje. Kilka lat później zdarzyło się, że gdy przebywałem w klasztorze w Casamari, gdzie zatrzymywał mnie więzami miłości mąż czcigodny Gerald, opat tego konwentu, i jego współbracia, którzy przywiązali mnie do siebie nierozwiązywalnym węzłem miłości, oto nadszedł dzień świąteczny, w którym na świętych apostołów wylane zostały dary Ducha Świętego i wlane $w$ ich dusze $z$ owym olejkiem duchowym, którym namaszczony był Jednorodzony Syn Boży hojniej nad swych towarzyszy. Ponieważ zaś nie by- 
łem zupełnie pozbawiony rozumienia tego świętego olejku i wiedziałem, że przynależy doń owa ofiara dziękczynna (Ps 50,23), a bardzo ubolewałem, że od tak długiego czasu nie dostąpiłem łaski tego tak wielkiego dobrodziejstwa, postanowiłem więc wyrecytować sobie tego dnia kilka psalmów na chwałę Ducha Świętego, ze względu na cześć należną tak uroczystemu świętu. Miałem przy tym nadzieję, że w ten dzień otrzymam coś od Tego, który daje wszystkim chętnie $i$ nie wymawiają $(\mathrm{Jk} 1,5)$. Tymczasem gdy wszedłem do oratorium i pokłoniłem się Bogu Wszechmogącemu przed świętym ołtarzem, naszła mnie pewna wątpliwość, dotycząca tajemnicy Trójcy Świętej. Jest rzeczą trudną - myślałem sobie - zarówno dla rozumu, jak i dla wiary, że trzy Osoby są jednym Bogiem, a jeden Bóg jest w trzech Osobach.

Gdy naszła mnie ta wątpliwość, zląkłem się wielce i ze strachu musiałem wzywać Ducha Świętego, którego święto przypadało tego dnia, prosząc Go, by zechciał mi objawić świętą tajemnicę Trójcy Świętej, bo w Nim właśnie obiecał nam Pan poznanie całej prawdy. Tak się modląc, zacząłem śpiewać psalmy, aby odśpiewać zamierzoną ich liczbę. Nagle ujrzałem w duchu kształt psalterium o dziesięciu strunach, a w kształcie tym ukazała mi się tajemnica Trójcy Świętej tak jasno i otwarcie, że zaraz musiałem zawołać: który bóg dorówna wielkościa naszemu Bogu? Ty jesteś Bogiem działającym cuda (Ps 77, 14-15) oraz Pan nasz jest wielki i zasobny w sity, mądrość Jego jest niewypowiedziana (Ps 147,5).

tłum. M. Beściak

„Kronos. Metafizyka, Kultura, Religia” 29 (2014), nr 2, s. 61-62.

Oryginał łaciński: Joachim von Fiore, Psalterium decem cordarum, red. K.V. Selge, MGH, Quellen zur Geistesgeschichte des Mittelalters, 20, Hannover 2009, s. 6-10.

\section{WAS JOACHIM OF FIORE A MYSTIC? \\ A FEW OBSERVATIONS ON THE APOCALYPTIC SPIRITUALITY OF THE CALABRESE ABBOT}

\section{SUMMARY}

The article attempts to examine the presence of mystical elements in the writings of the Calabrese exegete, Joachim of Fiore (circ. 1135-1202). The first part constitutes an overview of $12^{\text {th }}$ century characteristic elements of apocalyptic spirituality, as seen by Joachim. This spirituality is influenced by both personal reflections of this author and his intensive studies as well as current events, especially the crisis in the Church and the crusaders' movement, as well as spreading heresies in the West and the progressive expansion of Islam. The second part of the article analyzes two intuitions of 
mystical nature which Joachim of Fiore experienced during his stay at the Cistercian Casamari Abbey. He elaborates on them in his major writings - Expositio in Apocalypsim and Psalterium decem cordarum. The nature of these intuitions and their later influence on this author's writings allow the conclusion that we are dealing here with an experience that is mystical in nature, which, in turn, opened before Joachim some interpretative horizons that had been previously inaccessible in matters concerning the understanding (intelligentia) of inspired Writings.

Keywords: Joachim of Fiore; apocalyptic spirituality; mysticism; hermeneutics

Słowa kluczowe: Joachim z Fiore; apokaliptyczna duchowość; mistyka; hermeneutyka

\section{BIBLIOGRAFIA}

Chopra T.R., Mandala, w: Nuovo Dizionario delle religioni, red. H. Waldenfels, Cinisello Balsamo, Milano 1993, s. 536-537.

Czubak Scholle M., Św. Bernard z Clairvaux i początki mistyki cysterskiej, w: Przewodnik po filozofii średniowiecznej. Od św. Augustyna do Joachima z Fiore, red. A. Kijewska, Kraków 2012, s. 299-322.

Dante Alighieri, La Divina Commedia, Milano 1962.

Davy M.M., Initiation à la symbolique romane (XII siècle), Paris 1977.

Denifle H., Das Evangelium aeternum und die Commission zu Anagni, „Archiv für Literatur und Kirchengeschichte des Mittelalters" 1 (1885), s. 49-142.

Die Bildwelt der Diagramme Joachims von Fiore. Zur Medialität religiös-politischer Programme im Mittelalter, red. A. Patschovsky, Ostfildern 2003.

Expositio magni prophete Abbatis Ioachim in Apocalipsim [...] Venetiis 1527.

Gilson É., Historia filozofii chrześcijańskiej w wiekach średnich, thum. S. Zalewski, Warszawa 1987.

Gioacchino da Fiore, Commento a una profezia ignota, Opere di Gioacchino da Fiore: Testi e Strumenti, 10, red. M. Kaup, Roma 1999.

Gould W., Reeves M., Joachim of Fiore and the Myth of the Eternal Evangel in the Nineteenth and Twentieth Century. Revised and enlarged Edition, Oxford 2001.

Gregorovius F., Storia della città di Roma nel Medioevo, t. 4, Brugherio-Milano 1988.

Grundmann H., Per la biografia di Gioacchino da Fiore e di Raniero da Ponza, w: H. Grundmann, Gioacchino da Fiore. Vita e opere, Opere di Gioacchino da Fiore: Testi e Strumenti, 8, Roma 1997, s. 101-202.

Grundmann H., Studien über Joachim von Floris, Leipzig-Berlin 1927.

Grzegorz Wielki, Dialogi, tłum. E. Czerny, A. Świderkówna, Kraków 2007.

Grzeszczak J., Chwila jest bliska. Wizje końca w literaturze profetycznej (XII-XX wiek), Poznań 2011.

Grzeszczak J., Dall'Età dello Spirito Santo al New Age. Gioacchino da Fiore nella nuova religiosità, Poznań 2008.

Grzeszczak J., Joachim z Fiore. Średniowieczny przyczynek do teologii dziejów, Poznań 2006.

Ioachim Abbas Florensis, Enchiridion super Apocalypsim, w: Gioacchino da Fiore sull'Apocalisse, red. A. Tagliapietra, Milano 1994, s. 127-325.

Ioachim Abbas Florensis, Tractatus in expositionem vite et regule beati Benedicti cum appendice fragmenti (I) de duobus prophetis in novissimis diebus praedicaturis, Fonti per la storia dell'Italia medievale, Antiquitates, 29, red. A. Patschovsky, Roma 2008. 
Joachim z Fiore, List do wszystkich wiernych, thum. M. Beściak, D. Budzanowska, „Kronos. Metafizyka, Kultura, Religia” 29 (2014), nr 2, s. 81-85.

Joachim z Fiore, Psalterium o dziesięciu strunach, tłum. M. Beściak, „Kronos. Metafizyka, Kultura, Religia” 29 (2014), nr 2, s. 61-73.

Joachim z Fiore, Wprowadzenie do Apokalipsy, thum. P. Grad, „Kronos. Metafizyka, Kultura, Religia" 29 (2014), nr 2, s. 42-55.

Kaup M., De prophetia ignota - Eine frühe Schrift Joachims of Fiore, MGH, Studien und Texte, 19, Hannover 1998.

Kiełtyka S., Święty Bernard z Clairvaux, Kraków 1984.

Kołakowski L., Główne nurty marksizmu, t. 1: Powstanie, Poznań 2001.

Krąpiec M.A., Okresy i główne nurty filozofii, w: Wprowadzenie do filozofii, red. M.A. Krąpiec i in., Lublin $1996^{2}$, s. 33-87.

Le Goff J., Czasy katedr. Sztuka i społeczeństwo 980-1420, tłum. K. Dolatowska, Warszawa 2002.

Le Goff J., Kultura średniowiecznej Europy, thum. H. Szumańska-Grossowa, Gdańsk-Warszawa 2002.

Lessing G.E., Wychowanie rodzaju ludzkiego, tłum. H. Kahanowa, w: G.E. Lessing, Dzieła wybrane, t. 3, Warszawa 1959, s. 529-555.

Löwith K., Historia powszechna i dzieje zbawienia. Teologiczne przesłanki filozofii dziejów, tłum. J. Marzęcki, Kęty 2002.

Lubac, de H., La posterité spirituelle de Joachim de Flore. De Joachim à nos jours, Paris 2014.

Łukaszewska-Haberkowa J., Wstęp, w: Hildegarda z Bingen, Wizje, czyli poznaj drogi Pana, Kraków 2011, s. 7-13.

McGinn B., Antychryst. Dwa tysiace lat fascynacji czlowieka złem, thum. B. Cendrowska, Warszawa 1998.

McGinn B., Apocalyptic Spirituality. Treatises and Letters of Lactantius, Adso of Montier-en-Der, Joachim of Fiore, the Franciscan Spirituals, Savonarola, London 1980.

McGinn B., Joachim and the Sybil. An Early Work of Joachim of Fiore from Ms. 322 of the Biblioteca Antoniana in Padua, „Cîteaux. Commmentarii Cistercenses” 24 (1973), s. 97-138.

McGinn B., The Calabrian Abbot. Joachim of Fiore in the History of Western Thought, New York 1985.

McGinn B., Visions of the End. Apocalyptic Traditions in the Middle Ages, New York 1998.

Pensare per figure. Diagrammi e symboli in Gioacchino da Fiore. Atti del $7^{\circ}$ Congresso internazionale di studi gioachimiti, San Giovanni in Fiore - 24-26 settembre 2009, Opere di Gioacchino da Fiore: testi e strumenti, 23, red. A. Ghisalberti, Roma 2010.

Potestà G.L., Il tempo dell'Apocalisse. Vita di Gioacchino da Fiore, Roma-Bari 2004.

Rainini M., Disegni dei tempi. Il „Liber Figurarum” e la teologia figurativa di Gioacchino da Fiore, Opere di Gioacchino da Fiore: testi e strumenti, 18, Roma 2006.

Reeves M., Hirsch-Reich B., The Figurae of Joachim of Fiore, Oxford 1972.

Reeves M., The Influence of Prophecy in the Later Middle Ages. A Study in Joachimism, Oxford 1969, Notre Dame-London 19932.

Runciman S., Dzieje wypraw krzyżowych, t. 2: Królestwo Jerozolimskie i frankijski Wschód 1100-1187 , thum. J. Schwakopf, Katowice 2009.

Scattola M., Teologia polityczna, tłum. P. Borkowski, Warszawa 2011.

Sowiński A., Wstęp, w: G.E. Lessing, Dzieła wybrane, t. 1, Warszawa 1959, s. V-LXVIII.

Tagliapietra A., Gioacchino da Fiore e la filosofia, Saonara 2013.

Taubes J., Zachodnia eschatologia, thum. A. Serafin, Warszawa 2016.

Tovard G.H., Życie apostolskie i reforma Kościoła, w: Duchowość chrześcijańska. Późne średniowiecze i reformacja, red. J. Raitt, współpr. B. McGinn, J. Meyendorff, tłum. P. Blumczyński, Kraków 2011, s. 1-11.

Troncarelli F., Interior acies. Immagine e intuizione in Gioacchino da Fiore, „Florensia. Bollettino del Centro Internazionale di Studi Gioachimiti” 16-17 (2002-2003), s. 89-103. 
Vattimo G., Dopo la cristianità. Per un cristianesimo non religioso, Milano 2002.

Vauchez A., Duchowość średniowiecza, tłum. H. Zaremska, Gdańsk 2004.

Weigel G., Ostateczna rewolucja. Kościót sprzeciwu a upadek komunizmu, thum. W. Buchner, Poznań 1995.

Wilder A.N., The Rhetoric of Ancient and Modern Apocalyptic, „Interpretation” 25 (1971), s. 436$-453$.

Witek S., Duchowość religijna, w: Encyklopedia katolicka, t. 4, Lublin 1989, kol. 330-334.

JAN GrzeszCZAK - dr hab. teologii, prof. na Wydziale Teologicznym UAM, autor prac z dziedziny filozofii, teologii dziejów i historii Kościoła, zwłaszcza w średniowieczu: Joachim z Fiore. Średniowieczny przyczynek do teologii dziejów (2006), Pomiędzy utopia i eschatologiczna nadzieją. Idea papieża anielskiego $w$ średniowiecznym i renesansowym profetyzmie (2008), Chwila jest bliska. Wizje końca w literaturze profetycznej (XII-XX wiek) (2011). 